\title{
O ethos negativo e a arte de vanguarda: modernismo destrutivo das vanguardas históricas do início do século XX
}

Márcio Takeo Sobral Hagihara

Curso: Mestrado em Sociologia

Data da defesa: 28 de março de 2007

Orientador: Prof ${ }^{\mathrm{a}} \mathrm{Dr}^{\mathrm{a}}$ Mariza Veloso Motta Santos

\section{Resumo}

No tocante à análise sociológica da arte, a fase de transição entre o romantismo e o modernismo permanece obscura. Anteriormente ao modernismo construtivista, emergiu o modelo vanguardista de arte, caracterizado pelo profundo teor niilista, antitético e destrutivo.

A arte gauche dos realistas e dos impressionistas, bem como, as vanguardas negativas como o expressionismo, o surrealismo e o dadaísmo foram indispensáveis para a consolidação da autonomização do campo artístico por meio da criação de instituições, grupos e, principalmente, de um ethos artístico específico. A lógica da negatividade - resultado da rede de interações sociais e dos vários tipos de afiliações entre a intelligentsia e as elites políticas -, abriu caminho para a institucionalização de valores como a originalidade da obra de arte, a liberdade de criação e a expressão subjetiva, a tríade guiadora das ações sociais do artista e do processo criativo dos artistas de vanguarda no início do século XX.

A autonomização do campo artístico gravitou em torno de uma ética da convicção baseada na crítica social, denominada ethos negativo. Entretanto, os artistas não se limitaram a repetir uma mera formulação dos intelectuais de esquerda. A negação através da arte 
implicou especificidades. Uma história social de rechaçamentos e alijamentos alimentou a utopia dos artistas de vanguarda em destruir a esperança positivista e criar sua própria idéia de futuro. A arte modernista precisou arruinar o passado e o futuro para construir sua própria utopia.

Palavras-chave: Sociologia da Arte, Sociologia dos Intelectuais, vanguardas negativas, vanguardas européias, intelligentsia artística, século XX, autonomização do campo artístico, modernismo destrutivo, arte gauche, Surrealismo, Dadaísmo, Expressionismo, Bauhaus. 